\title{
Lipid profile in schoolchildren in Vitória - Brazil
}

\author{
Patrícia Casagrande Dias de Almeida ${ }^{1,2}$, Janine Pereira da Silva ${ }^{1}$, \\ Gustavo Carreiro Pinasco ${ }^{1,3}$, Christina Cruz Hegner ${ }^{1,4}$, Danielle Cabrini Mattos ${ }^{5}$, \\ Mateus Oliveira Potratz ${ }^{1}$, Lucas Santos Bravin ${ }^{1}$, Valmin Ramos Silva ${ }^{1,6}$, \\ Joel Alves Lamounier ${ }^{2,7}$.
}

DOI: http://dx.doi.org/10.7322/jhgd.110989

\begin{abstract}
Introduction: The growing prevalence of obesity is currently considered the most important nutritional disorder. It is characterized, according to the World Health Organization (WHO) as a worldwide epidemic in developing and developed countries. In an associated form, there is an increasing prevalence of dyslipidaemia. Aiming to improve the current situation and prevent the progression of the epidemic, the American Academy of Pediatrics recently reinforced the need for cholesterol screening in overweight children older than two years.

Objective: To determine overweight and lipid profile in children aged between six and nine years.

Methods: A descriptive, cross-sectional study with children from Vitoria, ES. For nutritional classification the Z-score > + 1 SD body mass index-for-age (according to WHO / 2007) was used; for the lipid profile the Atherosclerosis Prevention Guidelines in Childhood were used. Anthropometric measurements (weight, height, waist circumference and triceps skinfold thickness) followed the standard techniques described by WHO. Data were organized and analysed using SPSS, version 8.5 and calculated the absolute, relative and mean (SD) frequencies and the association between overweight, lipid profile and other variables is adopted as significant when $p<0.05$.

Results: The sample comprised a total of 511 children of both sexes ( $46.7 \%$ male), with a mean age of $101.6 \pm 11.1$ months. Overweight was found in 197 (38.5\%) children: overweight in $71(13.9 \%)$ and obesity in 126 (24.6\%). Total cholesterol was elevated in 167 (32.7\%) as were high LDL-C (136-27\%). High triglycerides were found in 21 participants (4.1\%). Significant association was found between waist circumference and high levels of triglycerides $(p=0.019)$ and HDL-C $(p=0.033)$.

Conclusion: Excess weight of the sample investigated is considered high and its health effects are important, with an increased total cholesterol greater than $32 \%$. The high levels of HDL-C are protective factors for coronary heart disease, although the lipid profile had been changed.
\end{abstract}

Keywords: dyslipidaemias, child, paediatric obesity.

\section{INTRODUCTION}

The growing prevalence of obesity is currently considered the most important nutritional disorder. It is characterized, according to the World Health Organization (WHO), as a worldwide epidemic in developing and developed countries ${ }^{1}$. A study conducted in São Paulo showed a prevalence of $30.59 \%$ of children and adolescents who were above the normal weight for their age, and of these more than half of the sample $(62.44 \%)$ were considered inactive or inadequately active in terms of physical activity ${ }^{2}$. That scenario is worrying because of the risk that children have of becoming obese adults with metabolic disorders and associated comorbidities ${ }^{3}$.

In an associated way the increasing prevalence of dyslipidaemia can also be noted, which, according to some studies, can be explained by excess weight gain. In Brazil,

\footnotetext{
1 Escola Superior de Ciências da Santa Casa de Misericórdia de Vitória (EMESCAM ) - Vitória (ES), Brasil

2 Universidade Federal de Minas Gerais (UFMG) - Belo Horizonte (MG), Brasil.

3 Faculdade de Medicina do ABC (FMABC) - Santo André (SP), Brasil.

4 Hospital Universitário Cassiano Antonio de Moraes (HUCAM) - Vitória (ES), Brasil.

5 Universidade Federal do Espírito Santo (UFES) - Vitória (ES), Brasil.

6 Hospital Estadual Infantil Nossa Senhora da Glória (HEINSG) - Vitória (ES), Brasil.

7 Universidade Federal São João Del Rey (UFSJ) - São João Del Rey (MG), Brasil.

Corresponding author: Patrícia Casagrande Dias de Almeida E-mai: casagrandepatricia@yahoo.com.br

Suggested citation: Almeida PCD, Silva JP, Pinasco GC, Hegner CC, Mattos DC, Potratz MO, Bravin LS, Ramos-Silva V, Lamounier JA. Lipid profile in school children in Vitória - Brazil. J Hum Growth Dev. 26(1): 61-66. Doi: http://dx.doi.org/10.7322/jhgd.110989

Manuscript submitted: Feb 10 2016, accepted for publication Feb 152016.
} 
such a comorbidity is present in $3.1 \%$ to $46.5 \%$ of children and adolescents from distinct regions of the country ${ }^{4}$.

Aiming to improve the current situation and to avoid the progression of the epidemic, the American Academy of Pediatrics recently reinforced the necessity of cholesterol tracking in overweight children over two years of age (Z-score $>+1$ s of body mass index/age). Prospective epidemiological studies have found that obesity and elevated levels of low-density lipoprotein (LDL) in children and adolescents are markers that help to predict arterial physiological changes, such as increased thickness of the carotid intima layer, which can be a precursor to early clinical cardiac events in young adults ${ }^{5}$.

Due to the importance in determining lipid levels, in addition to the anthropometric measurements of children and adolescents, it was planned to determine the prevalence of overweight and dyslipidaemia in children of six to nine years enrolled in public elementary schools in the city of Vitória, Espírito Santo, Brazil.

\section{METHODS}

This was a transversal and descriptive study of schoolchildren in the city of Vitória, state capital of Espírito Santo, with data collected between 2009 and 2010.

According to the municipal secretary of education - Secretaria Municipal de Educação (SEME), in 2009 there were 1850 children enrolled in the Vitória's schools at the age of six to nine years.. It was made a sampling for estimating proportions from confidence intervals for finite population adopting absolute error, with confidence level of $95 \%$, estimated prevalence of overweight in children of 7 to 10 years $\left(p=0.23\right.$ the study of Molina et al. $\left.{ }^{6}\right)$ which used $3.5 \%$ absolute error tolerated, reaching the casuistry number of 540 students for the study.

Therefore, the sample design consists of a probabilistic sample stratified by unequally sized conglomerates, selected in two stages: (a) at first the schools were selected, considering the school census data; (b) subsequently, within each of the selected schools, classes of participating students were selected through a list provided by the management of the schools. Eight schools have been randomly chosen, one for each of the six health regions of the city, except for the two regions with the highest number of schools that had as additional school randomly selected. Who had two raffled schools.

A probabilistic sample of 620 children selected by raffle constituted the study group to determine the prevalence of overweight and obesity. From this group, 511 took part in the blood collection step.

The measurement of weight and height followed the procedures recommended by the Ministry of Health ${ }^{7}$ and $\mathrm{WHO}^{8}$. The weight was measured on TANITA ${ }^{\circledR}$ portable, digital scales, with a capacity of $136 \mathrm{~kg}$ and $100 \mathrm{~g}$ divisions, with INMETRO certification. The children were barefoot, standardized, and properly positioned on the balance before their weight was readand recorded. The height was measured using an ALTURAEXATA ${ }^{\circledR}$ stadiometer, $214 \mathrm{~cm}$ in length and subdivided into $1 \mathrm{~mm}$ subdivisions, with INMETRO certification. The children were placed standing, without bending their knees, arms at the side of the body with their heels and shoulders erect and looking forward. For girls, the test was performed with hair down and without headdresses, for not to harm the taking of the measure. The abdominal circumference was measured with an inelastic tape measure, $150 \mathrm{~cm}$ in length and divided into $1 \mathrm{~mm}$ subdivisions, with INMETRO certification, and was performed by two assessors trained for this purpose. An appraiser kept the child's shirt raised while the other proceeded to take the measurement, which was obtained during normal exhalation, taking as reference the midpoint between the lowest rib margin and the iliac crest. The cut-off point adopted for the normal or altered abdominal circumference was proposed by Freedman et al. ${ }^{9}$ adjusted for age and sex. For the triceps skinfold thickness measurement, it a Lange Skinfold Caliper ${ }^{\circledR}$ adipometer was used, with a scale from 0 to $60 \mathrm{~mm}$ and an accuracy of $1 \mathrm{~mm}$. The skinfold was measured at the midpoint of the arm, between the acromion point of the scapula and the olecranon of the ulna. There were two measures taken and a third measurement was performed when the difference between the previous two was more than $2 \mathrm{~m}$, discarding the most outlier. The arithmetic average of the two values was used and the cut-off to identify obesity was the average above the 85 th percentile, in accordance with the recommendations of Seletezer et al. ${ }^{10}$.

From weight and height measures, the body mass index (BMI) was calculated by applying the formula: BMI $=$ weight $(\mathrm{kg}) /$ height $\left(\mathrm{m}^{2}\right)$. To determine the nutritional status, the BMI index for age (BMI/ ) in the $\mathrm{z}$ score was used, considering the following cut-off points: severe wasting (escore $\mathrm{z}<-3)$; wasting $(-3 \leq$ escore $\mathrm{z}<-2$ ); eutrophic $(-2 \leq$ escore $\mathrm{z} \leq+1)$; overweight $(+1<$ escore $\mathrm{z} \leq+2)$; obesity $(+2<$ escore $\mathrm{z} \leq+3)$; severe obesity (escore $z>+3)^{8}$.

For the laboratory evaluation, following the aseptic technique, using disposable materials properly identified and of recognized quality, $10 \mathrm{ml}$ of blood was collected by venipuncture in the upper limb, after fasting for 12 hours.

The samples were properly packaged and sent to the Central Laboratory Serological of Vitória - ES, for processing and analysis. The laboratory responsible for biochemical analysis has national and international certification of accreditation. They measured the serum levels of total cholesterol, HDL-C (high-density lipoprotein cholesterol), LDL-C (low-density lipoprotein cholesterol), VLDL-C (very low-density lipoprotein cholesterol), triglycerides and hs-CRP (high-sensitivity C-reactive protein).

The biochemical measurements were performed using dimension equipment of Siemens Healthcare Diagnostics Inc ${ }^{\circledR}$, the North American manufacturing company, which uses for total cholesterol the CHOL Flex Kit and enzymatic colorimetric method CHOP-POG; for triglycerides the TGL Flex Kit and enzymatic colorimetric method; for HDL-c the AHDL Flex Kit and enzymatic colorimetric method; for LDL-c the ALDL Flex Kit and enzymatic method. The adopted cutoffs follow the recommended criteria by the $\mathrm{V}$

Atherosclerosis Prevention in Childhood and Adolescence. 
Guideline of the Brazilian Society of Cardiology (Table 2) $)^{11}$

The information was organized in software Excel ${ }^{\circledR}$, version 2010 and analyses made in the software SPSS version 11.0. Descriptive statistics were taken(mean, standard deviation, median). The rejection level for the null hypothesis was 0.05 .

The study was approved by the Research Ethics Committee of Hospital Infantil Nossa Senhora da Glória (HINSG), protocol \#25/2010, and the Ethics Committee of the Federal University of Minas Gerais Research, protocol CAAE - \#0302.0.203.000-11. The children who presented changes in lipid profile were referred to the endocrinology clinic of Hospital Santa Casa de Misericordia de Vitoria ES.

\section{RESULTS}

A total of 511 children were evaluated, with 239 males $(46.77 \%)$ aged six to nine years old (mean age of $101.68 \pm 11.16$ months; mean height $131.57 \pm 7.97 \mathrm{~cm}$ and weight $30,34 \pm 8.38 \mathrm{~kg}$ ).

The assessment of nutritional status by BMI showed: wasting in $11(2.2 \%)$, eutrophy in $303(59.3 \%)$, overweight in $71(13.9 \%)$ and obesity in $126(24.6 \%)$.

The results of the dosage of serum lipids (total cholesterol, LDL cholesterol, HDL cholesterol and triglycerides) separated by gender and classified as normal, borderline or changed, are shown in Table 1.

Table 2 shows the relationship between the anthropometric variables and the results of lipid dosages,

Table 1: The results of the dosage of serum lipids (total cholesterol, LDL cholesterol, HDL cholesterol and triglyce- rides) separated by gender and classified as normal, borderline or changed according to $V$ Atherosclerosis Prevention in Childhood and Adolescence Guideline, in511 children from 6 to 9 years old, from municipal schoolin the city of Vitória, ES

\begin{tabular}{|c|c|c|c|c|c|c|c|c|}
\hline \multirow{2}{*}{ Lip } & \multirow{2}{*}{ Gender } & \multicolumn{2}{|c|}{ Desirable } & \multicolumn{2}{|c|}{ Borderline } & \multicolumn{2}{|c|}{ Altered } & \multirow{2}{*}{$\mathbf{P}$} \\
\hline & & $\mathbf{N}$ & $\%$ & $\mathbf{N}$ & $\%$ & $\mathrm{~N}$ & $\%$ & \\
\hline \multirow[t]{3}{*}{$\mathrm{CT}$} & $M+F$ & 201 & 39.3 & 133 & 26.0 & 177 & 177 & \\
\hline & M & 85 & 16.6 & 70 & 13.7 & 84 & 84 & \\
\hline & $\mathrm{F}$ & 116 & 22.7 & 63 & 12.3 & 93 & 93 & 0.175 \\
\hline \multirow[t]{3}{*}{ LDL-C } & $M+F$ & 305 & 59.7 & 159 & 31.1 & 47 & 47 & \\
\hline & M & 141 & 27.6 & 82 & 16.0 & 16 & 16 & \\
\hline & $\mathrm{F}$ & 164 & 32.1 & 77 & 15.1 & 31 & 31 & 0.102 \\
\hline \multirow{3}{*}{ HDL-C } & $M+F$ & 375 & 73.4 & - & - & 136 & 136 & \\
\hline & $\mathrm{M}$ & 179 & 35.0 & - & - & 60 & 60 & \\
\hline & $\mathrm{F}$ & 196 & 38.4 & - & - & 76 & 76 & 0.267 \\
\hline \multirow[t]{3}{*}{ TG } & $M+F$ & 450 & 88.1 & 40 & 7.8 & 21 & 21 & \\
\hline & M & 215 & 42.1 & 15 & 2.9 & 9 & 9 & \\
\hline & $\mathrm{F}$ & 235 & 46.0 & 25 & 4.9 & 12 & 12 & 0.429 \\
\hline
\end{tabular}

classified as normal, borderline or altered, without separation by gender. There was a significant association between obesity and overweight, altered abdominal circumference and altered triceps' skinfold with altered values of triglycerides. In addition, changed abdominal circumference and triceps skinfold demonstrated a significant association with HDL-C changes (below). (Table 2).

Table 2. Relationship between the anthropometric variables and the results of the dosage of serum lipids (total cholesterol, LDL cholesterol, HDL cholesterol and triglycerides) separated by gender and classified as normal, borderline or , according to $V$ Atherosclerosis Prevention in Childhood and Adolescence Guideline, in 511 children from 6 to 9 years old, from municipal schools in the city of Vitória, ES

\begin{tabular}{|c|c|c|c|c|c|c|c|c|c|c|c|}
\hline \multirow[t]{2}{*}{ Variável } & \multicolumn{3}{|c|}{ Triglycerides } & \multicolumn{3}{|c|}{ Total Cholesterol } & \multicolumn{2}{|c|}{ HDL-c } & \multicolumn{3}{|c|}{ LDL-c } \\
\hline & D & B & A & D & B & A & $\mathbf{N}$ & A\# & D & B & A \\
\hline \multicolumn{12}{|l|}{$\mathrm{BMI}$} \\
\hline Wasting & 8 & 3 & - & 3 & 1 & 17 & 9 & 2 & 4 & 4 & 3 \\
\hline Eutrophy & 278 & 20 & 5 & 120 & 86 & 97 & 233 & 70 & 188 & 89 & 26 \\
\hline Overweight & 64 & 3 & 4 & 28 & 21 & 22 & 48 & 23 & 39 & 26 & 6 \\
\hline Obesity & 100 & 14 & 12 & 50 & 25 & 51 & 85 & 41 & 74 & 40 & 12 \\
\hline $\begin{array}{c}\mathrm{p} \text { Value } \\
\text { AC }\end{array}$ & $0.000^{*}$ & 0.160 & 0.122 & 0.343 & & & & & & & \\
\hline - Normal & 392 & 30 & 11 & 168 & 118 & 147 & 325 & 108 & 261 & 132 & 40 \\
\hline - Altered & 58 & 10 & 10 & 33 & 15 & 30 & 50 & 28 & 44 & 27 & 7 \\
\hline $\begin{array}{c}\mathrm{p} \text {-Value } \\
\text { TST }\end{array}$ & $0.000^{*}$ & 0.328 & $0.033^{*}$ & 0.766 & & & & & & & \\
\hline - Normal & 349 & 25 & 9 & 148 & 108 & 127 & 294 & 89 & 233 & 144 & 36 \\
\hline - Altered & 101 & 15 & 12 & 53 & 25 & 50 & 81 & 47 & 72 & 45 & 11 \\
\hline$p$-Value & $0.000 *$ & 0.141 & $0.002^{*}$ & 0.522 & & & & & & & \\
\hline
\end{tabular}

$\mathrm{BMI}=$ body mass index, $\mathrm{AC}=$ abdominal circumference, $\mathrm{TST}=$ triceps skinfold thickness, $\mathrm{D}=$ desirable, $\mathrm{B}=$ borderline, $=$ altered * = statistical significance, HDL A\# = altered, value lower than recommended. 


\section{DISCUSSION}

Triglyceride levels were increased by $4.1 \%$ and they were bordering in $7.8 \%$ children, with an association with higher BMI scores $(\mathrm{p}<0.001)$, abdominal circumference $(p<0.001)$ and triceps skinfold $(p<0.001)$. The poor diet of children can explain lipid disorders found in children, being related to poor diet, high in fats and simple sugar, physical inactivity and erroneous family habits ${ }^{12}$.

Total cholesterol and fractions did not present a significant association with any of the anthropometric variables evaluated, except for low levels of HDL-C, which showed statical significance in relation to abdominal circumference $(p=0.033)$ and triceps skinfold $(p=0.002)$. The relationship between central adiposity and obesity has been observed in the last decade by other authors, being our data according to the literature ${ }^{13-15}$.

One study ${ }^{16}$ showed that low levels of HDL-C were associated in a significant manner to the presence of obesity. Another study involving teenagers also observed no relationship between abdominal obesity and changes in total cholesterol levels ${ }^{17}$.

The main dyslipidaemia associated with obesity is characterized by mild to moderate elevations of triglyceride and decreased HDL-C ${ }^{18}$. Although there is not strong evidence of triglyceride being related to atherosclerotic disease, serum levels are considered important for the assessment of dyslipidaemia ${ }^{19}$. However, in relation to cholesterol are associated with evidence of cardiovascular diseases, especially atherosclerosis ${ }^{11,20}$.
It is worth emphasizing that not only total cholesterol, but also HDL-C and LDL-C altered fractions are risks to health, given that low HDL-C levels are major risk factor for atherosclerosis ${ }^{11,20}$.

In the study, the measurement of BMI, abdominal circumference and triceps skinfold thickness did not differ in relation to gender of the individuals. We did not find adequate information to clash this data. The measurement of abdominal circumference has been used to identify prepubertal children with lipid alterations ${ }^{21}$, but the dimensions of skinfold are not used in routine.

There was also no difference between gender and total cholesterol levels, cholesterol fractions and triglycerides. A similar result was found by Pereira et al. ${ }^{17}$ in a study involving children with a median age of 11 years. In contrast, a study in

Florianópolis ${ }^{22}$, with children and adolescents between seven and eighteen, found that females had higher concentrations of total cholesterol and LDL-C.

In the study children with extremely high levels of HDL-C were also found, a fact that reflects a protective factor for coronary diseases in general ${ }^{23}$. Studies covering this age group are scarce in the Brazilian scientific community, and the study of this sample demonstrates the importance of this work.

In conlusion, the situations were identified in which an increase in triglycerides was associated with increased BMI, abdominal circumference and tricipital skinfold. There were high levels of overweight $(13,9 \%)$ and obesity $(24,6 \%)$ for children too.

\section{REFERENCES}

1. Pedroni JL, Rech RR, Halpern R, Marin S, Roth LR, Sirtoli MM et al. Prevalência de obesidade abdominal e excesso de gordura em escolares de uma cidade serrana no sul do Brasil. Ciênc Saúde Coletiva. 2013;18(5): 1417-25. DOI: http://dx.doi.org/10.1590/S1413-81232013000500027

2. Cabrera TFC, Correia IFL, Santos DO, Pacagnelli FL, Prado MTA, Silva TD, et al. Analisys of the prevalence of overweight and obesity and the level of physical activity in children and adolescents of a southwestern city of São Paulo. J Hum Growth Dev. 2014;24(1): 66-72. DOI: http://dx.doi.org/10.7322/jhgd.73455

3. Azambuja APO, Netto-Oliveira ER, Oliveira AAB, Azambuja MA, Rinaldi W. Prevalência de sobrepeso/ obesidade e nível econômico de escolares. Rev Paul Pediatr 2013;31(2): 166-71. DOI: http://dx.doi. org/10.1590/S0103-05822013000200006

4. Alcântara Neto ODA, Silva RCR, Assis AMO, Pinto EJ. Factors associated with dyslipidemia in children and adolescents enrolled in public schools of Salvador, Bahia. Rev Bras Epidemiol. 2012;15(2): 335-45. DOI: http://dx.doi.org/10.1590/S1415-790X2012000200011

5. Ribas SA, Silva LCS. Anthropometric indices: predictors of dyslipidemia in children and adolescents from north of Brazil. Nutr Hosp. 2012;27(4): 1228-35. DOI: http://dx.doi.org/10.3305/nh.2012.27.4.5798.

6. Molina MCB, Faria CP, Monteiro MP, Cade NG, Mill JG. Fatores de Risco cardiovascular em crianças de 7 - 10 anos de área urbana, Vitória, Espírito Santo, Brasil. Cad Saúde Pública. 2010;26(5): 909-17. DOI: http://dx.doi.org/10.1590/S0102-311X2010000500013

7. Brasil. Ministério da Saúde. Secretaria de Políticas de Saúde. Departamento de Atenção Básica. Saúde da criança: acompanhamento do crescimento e desenvolvimento infantil. Brasília: Ministério da Saúde; 2002.

8. World Health Organization (WHO). The WHO Child Growth Standards for 5-19 age children. WHO; 2007.

9. Freedman DS, Serdula MK, Srinivasan SR, Berenson GS. Relation of circumferences and skinfold thicknesses to lipid and insulin concentrations in children and adolescents: the Bogalusa Heart Study. Am J Clin Nutr. 1999;69(2): 308-1. 
10. Seltzer CC, Mayer JA. Simplified criteria for obesity. Postgrad Med. 1965;38: A101-7.

11. Sociedade Brasileira de Cardiologia. A "V Diretriz Brasileira de Dislipidemias e Prevenção da Aterosclerose". Arq Bras Cardiol. 2013;101(4 Supl.1): 1-22. DOI: http://dx.doi.org/10.5935/abc.2013S010e

12. Kruger GRO, Ribas-Silva RC. Perfil lipídico e índice de massa corporal de escolares de um colégio estadual da região centro-ocidentarl do Paraná. Adolesc Saude. 2014;11(4): 54-60.

13. Manios Y, Magkos F, Christakis G, Kafatos AG. Changing relationships of obesity and dyslipidemia in Greek children: 1982-2002. Prev Med. 2005;41(5-6): 846-51. DOI: http://dx.doi.org/10.1016/j.ypmed.2005.08.008

14. Miller S, Manlhiot C, Chahal N, Cullen-Dean G, Bannister L, McCrindle BW. Impact of increasing adiposity in hyperlipidemic children. Clin Pediatr (Phila). 2008;47(7): 679-84. DOI: http://dx.doi. org/10.1177/0009922808315214

15. Solano L, Velasquez E, Naddaf G, Paez M. Lipid profile from low socioeconomic level preschool children. Valencia, Venezuela. Acta Cient Venez. 2003;54(4): 254-62.

16. Lavrador MSF, Abbes PT, Escrivão MAMS, Taddei JAAC. Riscos cardiovasculares em adolescentes com diferentes graus de obesidade. Arq Bras Cardiol. 2011;96(3): 205-11. DOI: http://dx.doi.org/10.1590/ S0066-782X2010005000166

17. Pereira PB, Arruda IKG, Cavalcanti AMTS, Diniz AS. Perfil Lipídico em Escolares de Recife - PE. Arq Bras Cardiol. 2010;95(5): 606-13. DOI: http://dx.doi.org/10.1590/S0066-782X2010005000136

18. Novaes JF, Franceschini SCC, Priore SE. Obesidade infantil: um distúrbio nutricional em ascensão no mundo moderno. Nutrire Rev Soc Bras Aliment Nutr. 2007;32(1): 59-75.

19. Seki MO, Matsuo T, Seki M. Colesterol não-HDLem escolares de 7 a 17 anos em um município brasileiro. Rev Panam Salud Publica. 2007;21(5): 307-12. DOI: http://dx.doi.org/10.1590/S1020-49892007000400006

20. Carvalho DF, Paiva AA, Melo ASO, Ramos AT, Medeiros JS, Medeiros CCM, et al. Perfil lipídico e estado nutricional de adolescentes. Rev Bras Epidemiol. 2007;10(4): 4911-8. DOI: http://dx.doi.org/10.1590/ S1415-790X2007000400007

21. Silva JR, Enes CC. Relação entre estado nutricional e perfil lipídico de adolescentes escolares. Anais do IV Encontro de Iniciação em Desenvolvimento Tecnológico e Inovação. Campinas: PUC; 2014.

22. Giuliano ICB, Coutinho MSSA, Freitas SFT, Pires MMS, Zunino JN, Ribeiro RQC. Lipides séricos em crianças e adolescentes de Florianopolis, SC - Estudo Floripa Saudável 2024. Arq Bras Cardiol. 2005;85(2): 85-91. DOI: http://dx.doi.org/10.1590/S0066-782X2005001500003

23 Ribeiro RQC, Lotufo PA, Lamounier JA, Oliveira RG, Soares JF, Botter DA. Fatores adicionais de risco cardiovascular associados ao excesso de peso em crianças e adolescentes. O estudo do coração de Belo Horizonte. Arq Bras Cardiol. 2006;86(6): 408-18. DOI: http://dx.doi.org/10.1590/S0066$-782 \times 2006000600002$

This article is distributed under the terms of the Creative Commons Attribution 4.0 International License (http://creativecommons.org/licenses/by/4.0/), which permits unrestricted use, distribution, and reproduction in any medium, provided you give appropriate credit to the original author(s) and the source, provide a link to the Creative Commons license, and indicate if changes were made. The Creative Commons Public Domain Dedication waiver (http://creativecommons.org/publicdomain/zero/1.0/) applies to the data made available in this article, unless otherwise stated. 


\section{Resumo}

Introdução: A prevalência crescente da obesidade é atualmente considerado o distúrbio nutricional mais importante. Caracteriza-se, de acordo com a Organização Mundial de Saúde (OMS) como uma epidemia mundial nos países em desenvolvimento e desenvolvidos. Numa forma associada, há um aumento da prevalência da dislipidemia. Com o objetivo de melhorar a situação actual e prevenir a progressão da epidemia, a Academia Americana de Pediatria reforçou recentemente a necessidade de triagem de colesterol em crianças com sobrepeso com idade superior a dois anos.

Objetivo: Determinar o perfil sobrepeso e lipídico em crianças com idade entre seis e nove anos. Método: Estudo descritivo, transversal com crianças de Vitória, ES. Para a classificação nutricional do Z-score > + 1 SD índice para idade de massa corporal (segundo a OMS / 2007) foi utilizada; para o perfil lipídico as Diretrizes Prevenção da Aterosclerose na Infância foram utilizados. As medidas antropométricas (peso, altura, circunferência da cintura e dobra cutânea tricipital) seguiu as técnicas padrão descritas pela OMS. Os dados foram as frequências (SD) absolutos, relativos e média e a associação entre, perfil lipídico excesso de peso e outras variáveis organizados e analisados usando SPSS, versão 8.5 e calculada é adotado como significativo quando $p<0,05$.

Resultados: A amostra foi composta por um total de 511 crianças de ambos os sexos (46,7\% do sexo masculino), com idade média de 101,6 \pm 11,1 meses. O excesso de peso foi encontrado em 197 $(38,5 \%)$ crianças: Excesso de peso em 71 (13,9\%) e obesidade em 126 (24,6\%). O colesterol total foi elevada em 167 (32,7\%) eram como níveis elevados de LDL-C (136-27\%). Triglicéridos elevados foram encontrados em 21 participantes (4,1\%). associação significativa foi encontrada entre a circunferência da cintura e níveis elevados de triglicéridos ( $p=0,019)$ e HDL-C $(p=0,033)$.

Conclusão: O excesso de peso da amostra investigada é considerada alta e seus efeitos sobre a saúde são importantes, com um colesterol total aumentou mais de 32\%. Os altos níveis de HDL-C são fatores de proteção para a doença cardíaca coronária, embora o perfil lipídico tinha sido mudado.

Palavras-chave: dislipidemias, criança, obesidade pediátrica. 